\title{
A life cycle assessment of distributed energy production from organic waste: two case studies in Europe
}

Sara Evangelisti ${ }^{1}$, Roland Clift ${ }^{2}$, Carla Tagliaferri ${ }^{1}$, Paola Lettieri ${ }^{1 *}$

${ }^{1}$ Chemical Engineering Department, University College London, Gower Street, London, WC1E7JE, UK

${ }^{2}$ Centre for Environmental Strategy, The University of Surrey, Guildford, Surrey, GU2 7XH, $\mathrm{UK}$

*Author for correspondence: Prof Paola Lettieri. Department of Chemical Engineering, UCL. Torrington Place, London WC1E 7JE, (UK), Roberts Building, Room 312. Phone: +44 (0) 207679 7867; Fax: +44 (0) 207383 2348. Email: p.lettieri@ucl.ac.uk

\section{ABSTRACT}

By means of the life cycle assessment methodology, the purpose of this study is to assess the environmental impact when biomethane from organic waste produced at residential level is used to supply energy to a group of dwellings in the distributed generation paradigm. Three different Combined Heat and Power systems, such as fuel cells, Stirling engine and micro gas turbine, installed at household level are assessed in two different settings: one in Northern Europe (UK) and one in Southern Europe (Italy). Different operating strategies are investigated for each technology. Moreover, marginal electricity production technologies are analysed to assess their influence on the results. This study has demonstrated that the type of bio-methane fed micro-CHP technology employed has a significantly different environmental impact: fuel cells are the most environmentally friendly solution in every category analysed; Stirling engines, although can supply heat to the largest number of dwellings are the least environmentally friendly technology. However, key factors investigated in the model presented in this paper influence the decision making on the type of technology adopted and the operating strategy to be implemented.

Keywords: distributed generation; biomethane; life cycle assessment; micro-CHP; food waste.

\section{INTRODUCTION}

Currently, energy systems are dominated by large plants fed by conventional fuel, operating in central locations and connected with final users via transmission and distribution networks. However, recent years have seen a trend in power generation towards Distributed Generation 
(DG), using small-scale energy conversion units situated close to the point of energy use. The centralized generation paradigm is increasingly questioned in view of the vulnerability of complex systems and the scarcity of traditional fossil fuels commonly used in large scale plants. On the other hand, small scale distributed conversion technologies can advantageously use fuels locally available, often produced by Renewable Energy Sources (RES), e.g. biogas from wastes and wood biomass, improving the environmental sustainability and potentially the resilience of the energy system.

Biogas represents an alternative source to fossil fuels which can lead to a reduction of $\mathrm{CO}_{2}$ emissions as well as meeting European and National targets for the proportion of renewable energy (European Union, 2009). Biogas is produced mainly by anaerobic digestion of biodegradable material such as biomass, animal manure, sewage and waste.

The possibility to produce biogas from organic residues has changed the perception of waste in the last few years: it is regarded not as refuse but more as a potential energy source. In the European Union (EU), between 118 and 138 million tons of biowaste are produced per year, about $70 \%$ of which is from Organic Fraction of Municipal Solid Waste (OFMSW) (European Union, 2010).

The biogas, which contains mainly methane and carbon dioxide, can be used as a fuel for CHP (Combined Heat and Power) production (Borello et al., 2013). It is a potential alternative to natural gas and can reduce emissions of greenhouse gases (GHGs) since the carbon dioxide produced by the combustion of biogas is usually considered biogenic and therefore does not contribute to GHG inventories (EPA, 2011).

Micro Combined Heat and Power (micro CHP) units simultaneously produce heat and power for a single building, and can possibly be fed with biogas. Several micro CHP technologies have been developed recently for applications at domestic scale. A general list includes reciprocating engines, Stirling engines, low and high temperature fuel cells, microturbines, photovoltaic systems and Organic Rankine Cycle (ORC) systems. It has been suggested that replacement of gas heating boilers may open up a mass market for micro-CHP (Pehnt, 2008). At present, the UK is the largest European boiler market, with 17 million systems currently installed and 1.6 million boilers sold annually, primarily due to the UK's aversion to heat distribution systems, such as district heating (DECC, 2013). The Department of Energy and Climate Change (DECC) has estimated that substitution of condensing boilers 
and electricity drawn from the grid with micro CHP systems in the UK might reduce emissions of $\mathrm{CO}_{2}$ by up to 2.1 tons per year per household (DECC, 2011). Conversely, in Italy, micro generation technologies are very limited due mainly to the opposition of the electricity and natural gas industries. Therefore, micro-cogeneration is negligibly contributing to the final Italy energy mix.

\subsection{Objective}

In previously published work (Evangelisti et al., 2014) we investigated the environmental performance of different scenarios for the use of biogas produced from anaerobic digestion (AD) of OFMSW to supply energy to a group of dwellings in the UK context. We concluded that, to reduce the environmental impact, the biogas should be used for the production of electricity and heat from micro-CHP units rather than for the production of heat through condensing boilers. Moreover the study highlighted the convenience of using existing natural gas pipelines and the resultant necessity to upgrade the biogas to biomethane for distribution. However, only one micro-CHP technology was investigated in that study assuming a fixed operating strategy for the system during the year. This present work goes further, investigating four new aspects. The driving questions of the study are:

1. What is the most environmentally friendly micro-CHP technology run with biomethane? Different micro CHP technologies for distributed generation are assessed: micro gas turbines and Stirling engines, led by different operating strategies, are compared with a SOFC (Solide Oxide Fuel Cell) micro-CHP system in two distinct geographical contexts in Europe. Two different areas are investigated: a northern European location (UK) and a southern European one (Italy)..

1.1. How does the operating strategy affect the environmental impact of micro-CHP systems in the distributed generation paradigm? Three operating strategies are investigated for the three technologies assuming that they have to satisfy either a: full thermal demand, half thermal demand or a full electricity demand

1.2. How do the geographic and climate context influence the scenario's selection and the emission savings? This is analysed as a function of the different $\mathrm{H} / \mathrm{P}$ (Heat to Power) ratio of the technologies considered, availability of the OFMSW feedstock, and the different energy mix. For the latter, 
1.2.1. the electricity production mix is initially taken as the reference technology and then substituted with the marginal electricity production technology specific for the geographic area.

To evaluate how the geographic and climate context affect these results, two areas are investigated: a Northern European location, i.e. the Royal Borough of Greenwich in south east London (UK), and a Southern European location, i.e. the Municipality of Livorno in the Toscana region (Italy). The two cases are comparable in terms of both population and current approaches to waste management. In fact landfill is still the most prevalent treatment in both areas followed by incineration. Moreover, both boroughs are suited for biological treatment of waste according to the recent interest of UK and Italy in advanced waste management and use of renewable energy.

Different tools exist to evaluate the environmental impacts of a process or a service. Life Cycle Assessment is recognised as one of the best tools available, in order to avoid burdens shifting, i.e. 'minimizing impacts at one stage of the life cycle, or in a geographic region, or in a particular impact category, while helping to avoid increases elsewhere' (Manfredi and Pant, 2011). Previous LCA studies of micro CHP systems fed with biogas are limited or incomplete (Lunghi et al., 2004; Pöschl et al., 2010; Patterson et al., 2011). Lunghi et al. (2004) focused on a Molten Carbonate fuel cell fed by biogas from landfill, while Pöschl et al. (2010) performed an energy efficiency evaluation of various feedstock and biogas utilization pathways. Studies have been published on carbon footprint of micro - CHP units rather than a holistic environmental appraisal, and none has evaluated biogas as a fuel (Hawkes et al., 2007; Giannapoulos and Fonti, 2011; Staffell et al., 2011). A few studies have focused on the environmental impacts of different micro-CHP technologies (Pehnt, 2008; Halliday et al., 2004) but did not examine any alternative fuel other than natural gas.

\section{METHODS}

\subsection{LCA approach}

Life Cycle Assessment is one of the most developed and widely used environmental assessment tools for comparing alternative technologies when the location of the activity is defined (Clift et al., 2000; Clift, 2013). LCA quantifies the amount of materials and energy used over the complete supply chains (i.e. life cycles) of goods and services and identifies 
emissions and wastes associated with the life cycles. Moreover, it helps to determine "hot spots" in the system, i.e. those parts that have the most significant environmental impact and should be improved in the first instance, thus enabling identification of more environmentally sustainable options. The International Standards ISO 14040 and 14044 (ISO, 2006) provide the methodological framework for LCA applications and define its main phases.

In the definition of LCA, the term 'product' includes not only material products but can also include service systems, for example waste management systems. In LCA, a multifunctional process is defined as an activity that fulfils more than one function, such as waste management process dealing with waste and generating energy. It is then necessary to find a rational basis for allocating the environmental burdens between the functions. The ISO standards recommend that the environmental benefits of recovered resources should be accounted for by broadening the system boundaries to include the avoided burdens of conventional production, an approach referred as system expansion (Eriksson et al, 2006). The same approach is recommended for product labelling provided that it can be proved that the recovered material or energy is actually used (PAS2050, 2011). The substitution by system expansion (also called avoided burden method) is applied here. Following the methodological approach of Clift et al. (2000) for Integrated Waste Management (IWM), a pragmatic distinction between Foreground and Background is made in this study, considering the first as 'the set of processes whose selection or mode of operation is affected directly by decisions based on the study' and the second as 'all other processes which interact with the Foreground, usually by supplying or receiving material or energy'.

The burdens are evaluated here considering three categories (Clift et al., 2000): direct burdens, associated with the use phase of the process/service; indirect burdens, due to upstream and downstream processes (e.g. energy provision for electricity or diesel for transportation); and avoided burdens associated with products or services supplied by the process (e.g. energy or conventional fertilizer produced by the system). Following conventional practices (e.g. PAS 2050, 2011), secondary data for the indirect and avoided burdens are taken as the averages for the background system, while primary data are used for the Foreground operations, as possible. 


\subsection{Goal and Scope definition}

In the system under analysis, the total amount of food waste produced in each case study is used to produce the biogas which is later upgraded to biomethane to supply part of the energy demand in the same area. This system is compared with a reference scenario, where the energy is supplied via conventional technologies. The Foreground data used are site-specific where possible. Otherwise, average data from the literature and specific datasets are used; in this work, the background data are regionalised in the sense that they refer to the UK and Italian energy system rather than the European average (PE International, 2014).

This study considers the following impact categories: Abiotic resources Depletion (AD) quantifiesthe primary energy consumption from fossil fuel resources; Global Warming (GW) measures the greenhouse effect; Acidification (A) quantifies the effect of acid rain and deposition; Photochemical Oxidant Creation (POC) quantifies the effect of formation of tropospheric ozone and resultant photo-smog (Guineè, 2002); and Nutrient Enrichment (NE) is an indicator of surface water eutrophication (Wenzel et al., 1997). These impact categorieshave been chosen given their environmental importance and the fact that they are internationally accepted (ISO, 2006); they are based upon distinct identifiable environmental mechanisms and ensure that the results are robust enough to form a basis for further consideration or decisions. LCA modeling is undertaken using the widely used software $\mathrm{GaBi}$ 6, implementing different datasets (PE International, 2014).

Figure 1 shows the system analysed in this study and its boundaries. The input to the system is the OFMSW generated by the total population of the area transported to the transfer station (TS) where waste is unloaded from collection vehicles and briefly held to be reloaded into larger long-distance vehicles for shipment to the energy recovery facilities. Generation and collection of the waste from the single house to the transfer station are outside the system boundaries of this study and therefore are not included in the analysis. This is because the generation and collection phase is a complex system and several assumptions would have been needed to model it, changing the scope of this paper. The waste is assumed to be sourceseparated; thus no mechanical separation is considered before pre-treatment for digestion. The OFMSW is transported from the transfer station (TS) to the anaerobic digestion plant where the biogas is generated. Different transportation distances are considered in the two cases (i.e. $\mathrm{UK}$ and Italy). Transportation of the digestate from the AD plant to the agricultural field is 
considered as well. The biogas is then upgraded to biomethane and the existing natural gas pipelines are used for the distribution (represented by "Fuel transport" in Figure 1), to fulfill the annual energy demand of some of the households, which is taken as an output of the system. This is used to assess the amount of energy that can be met by the foreground system and the emissions that can consequently be avoided. The three different micro-CHP technology scenarios fed by biomethane are shown in the Foreground: internal reforming solid oxide fuel cell (SOFC) unit, Stirling Engine, and Micro Gas turbine. System expansion is applied to evaluate the avoided burdens associated with the substitution of a 'reference scenario'. This includes technologies for the waste treatment process, commercial fertilizer production and energy production at dwelling level (shown as avoided processes in Figure 1). Landfill plant with electricity generation is substituted by the biological treatment; commercial fertiliser is substituted by the digestate; electricity from the grid (with the country-specific average mix of sources) and thermal energy from a natural gas condensing boiler with $85 \%$ efficiency is substituted by the energy produced by micro CHP systems (Staffell et al., 2011; Møller et al., 2009). Only the use phase is considered here, given that previous studies have already demonstrated a nugatory contribution of the manufacturing phase to the total environmental impact for micro-CHP systems, and for the AD and landfill plants (Staffell et al., 2011; Mezzullo, 2013; Zhang et al., 2013).

In order to assess the amount of energy that can be met by the foreground system (and the emissions that can then be avoided) the functional unit used in this study is the total amount of OFMSW produced in the area (Greenwich or Livorno), which is taken as an input to the system. The functional unit is then 45,000 tons/year OFMSW for the Borough of Greenwich and 36,800 tons/year OFMSW for the Municipality of Livorno.

\subsubsection{A case study in UK: the London Borough of Greenwich}

The total annual production of food waste in the Royal Borough of Greenwich is estimated as 45,000 tons/year: in fact, considering the total number of households in the borough (i.e. 102,000), the average food waste production per single household is $441 \mathrm{~kg}$ per year (Royal Borough of Greenwich, 2011). 
Specific distances between the waste treatment plants are considered in the analysis, i.e $30 \mathrm{~km}$ for the landfill site, $50 \mathrm{~km}$ between the TS and the anaerobic digestion plant and $30 \mathrm{~km}$ for the average distance between the AD plant and the farmland where the digestate is used.

Energy demand of a single-family house consists usually of electricity for appliances and electricity or heat for hot water and space heating. In this study, for the sake of simplicity, only electricity and space heating demands are considered. Demand estimates are taken from Hawkes et al. (2007): the dwelling considered is an average UK house, with a floor area of 85 $\mathrm{m}^{2}$, where the heating system provides a resultant ambient temperature of $25^{\circ} \mathrm{C}$ during heating hours. The average number of occupants was 2.7 (Hawkes et al., 2007).Hawkes et al. defined a specific schedule for the heating time over the months and days in a year, along with occupancy schedules for every room of the house and the use of specific appliances. The heating system is assumed to operate from beginning of September to end of April. The resulting annual space heating demand for a single dwelling is then $13,600 \mathrm{kWhth}$, while the annual electricity demand is 4,300kWhe.

\subsubsection{A case study in Italy: the Municipality of Livorno}

Livorno has a population of 156,800 inhabitants, distributed between 71,600 households (ISTAT, 2012). The organic waste, representing 35\% of the total MSW generated, amounts to $513 \mathrm{~kg} /$ year per household, corresponding to a total production of OFMSW of 36,800 ton/year (ISPRA, 2012).

The distance considered between the TS and the plants in the Italian case study are: $16 \mathrm{~km}$ for the landfill plant; $25 \mathrm{~km}$ for the AD plant; and $10 \mathrm{~km}$ for the farmland.

As for the UK, a typical house is considered to estimate the space heating and electricity demand. The data are taken from Liso et al. (2011) who simulated a single-family house with $80 \mathrm{~m}^{2}$ heated area. The temperature set-point was $21^{\circ} \mathrm{C}\left(4^{\circ} \mathrm{C}\right.$ less than the UK case study), while the average number of occupants was 2.7. Liso et al. considered a specific pattern for lighting and appliances, in accordance to international standards. The annual space heating and electricity demand for a typical house in Livorno is 7,000 kWhth and 3,000 kWhe respectively. 


\subsection{Life cycle inventory}

The direct burdens for the foreground systems include: the fugitive emissions of methane in the $\mathrm{AD}$ plant; the use of the digestate; the cleaning and upgrading of the biogas to biomethane; the transportation of the biomethane (fugitive emissions); and the emissions associated with the use of micro CHP system. The indirect burdens include the transportation of the waste, the supply of electricity, the supply of heat and water to the system. Finally, the avoided burdens include the emissions associated with the reference scenario that is substituted by the Foreground systems.

\subsubsection{Reference scenario}

A specific composition for the OFMSW is considered (Table 1), based on each case study area (MTT, 2010). The landfill plant considered is modelled as a typical municipal waste landfill for a European country. In addition to transport from the TS to the plant, the model includes landfill gas collection (with $50 \%$ recovery efficiency), its treatment and its use for electricity and leachate treatment.

The total environmental impact of electricity recovery at a UK landfill has been calculated by Evangelisti et al. (2013b); these values are reported in Table 2 together with the values for the Italian case study presented here. The production of electricity with a conventional system is evaluated considering the average UK and Italian mix of technologies and fuels; the data used is based on the dataset elaborated by PE International (2014). In the UK, the electricity is produced from natural gas (39.3\%), hard coal (32.1\%) and nuclear energy (22\%), wind $(0.4 \%)$, heavy fuel oil (1.8\%), biomass (1\%), hydro (2\%) and others (1.4\%). In Italy, 34.8\% of the electricity is produced by natural gas, followed by $16.6 \%$ of hydroelectric energy, $12.4 \%$ of hard coal, $30.8 \%$ of heavy fuel oil, $1.6 \%$ of geothermal and the remaining part of other sources. These differences are reflected in the environmental impact associated with the production of $1 \mathrm{MJ}$ of electricity from the grid, and in particular in the carbon footprint which is equal to $0.155 \mathrm{~kg}$ of $\mathrm{CO}_{2}$ eq in the $\mathrm{UK}$ and $0.161 \mathrm{~kg}$ of $\mathrm{CO}_{2}$ eq in Italy (PE International, 2014). The production of heat is evaluated considering a natural gas-fired condensing boiler with an efficiency of $85 \%$ (Staffell et al., 2011). In the UK more than half of the natural gas comes from national resources, while only $10 \%$ of the total natural gas supplied in Italy comes from internal suppliers. This leads to a different environmental impact associated with 
the production and distribution of $1 \mathrm{~kg}$ of natural gas in the two countries: the carbon footprint is $0.613 \mathrm{~kg}$ of $\mathrm{CO}_{2}$ eq in Italy, while it is $0.208 \mathrm{~kg}$ of $\mathrm{CO}_{2}$ eq in the UK (PE International, 2014). The average burdens reported by Møller et al. (2009) for the production of N, P and K fertilisers are used in this study.

\subsubsection{Marginal electricity production technology}

The importance of considering a specific substitution technology when evaluating the avoided burdens is well established (e.g. Fruergaard et al., 2009; Turconi et al., 2011). Marginal data represent the production technology actually affected by the induced change to the system, in this case the electricity generation displaced by electricity recovery from waste (Fruergaard et al., 2009).

Various approaches have been proposed to define the marginal technology for electricity production (Fisher et al., 2006; CCC, 2008; Weidema et al., 1999). Staffell et al. (2011) suggest that 'the short-term marginal electricity production technologies in the UK are coal and combined cycle gas turbine (CCGT) plants which are 'marginal' or 'peaking' plants (which) respond to instantaneous changes in the nationwide electricity demand by varying their output'.

The work of Turconi et al. (2011) has been taken as reference to identify the marginal technologies for electricity production in Italy. According to this study, the increased electricity production from waste in Italy will most likely reduce the need for additional electricity production from natural gas (Turconi, Butera, Boldrin, et al., 2011). However, to complete the IT case study, a coal plant is considered as in the UK scenarios.

The country-specific emissions associated with coal and CCGT plants are taken from PE International (2014).

\subsubsection{Distributed generation scenarios: anaerobic digestion}

A mesophilic reactor, working at an average temperature of $35^{\circ} \mathrm{C}$, with a continuous, single stage mixed tank in wet regime $(12 \%$ dry matter) is assumed for the anaerobic digestion process. The parameters used to model the AD plant and biogas production are the same for both case studies in UK and Italy and they can be found in Evangelisti et al. (2013b) and in the supplementary information.

The digestate is the residue from the anaerobic digestion. It can be used unseparated or divided into solid and liquid fractions. Use of the digestate to replace commercial fertilizers 
depends on specific countries' legislation. In both the UK and Italy, use of digestate for fertilisation of crops is permitted (PAS110, 2010; Italian Parliament, 2012). In the UK, several on-going projects are investigating the potential of applying such substitution by characterizing and quantifying the nutrients, crop uptake and emissions to air, soil and water compared to conventional fertilisation (WRAP, 2011). In Italy, the legislation on the definition and use of digestate from OFMSW is currently under review. In this study, it is assumed that the quality and spreading of the digestate complies with national regulations with regards to the use of organic fertilizers. The modelling parameters are referred to a sandy soil, taken from Boldrin et al. (2011). A carbon sequestration factor is considered to take into account the amount of carbon in the digestate retained in the soil according to the values reported in Moller et al. (2009). The electricity demand for the spreading of the digestate is assumed to be 4.7 MJ per ton of digestate (Berglund and Börjesson, 2006 and Dalemo et al., 1997).

The environmental impacts associated with the treatment of the OFMSW in the AD plant and with the production and use of digestate are listed in Table 3 (Evangelisti et al., 2013b).

\subsubsection{Biogas upgrading and distribution to micro-CHPs}

In this work the following biogas composition is assumed for both countries: $63 \%$ of $\mathrm{CH} 4$, $30 \%$ of $\mathrm{CO} 2,1 \%$ of $\mathrm{N} 2,6 \%$ of $\mathrm{H} 2 \mathrm{O}, 600$ ppm of H2S (Zhang, El-Mashad, Hartman, et al., 2007). Producing biomethane from biogas requires an upgrading process to remove mainly $\mathrm{CO}_{2}, \mathrm{H}_{2} \mathrm{~S}$ and to increase the energy density. A desulfurization unit is assumed to be installed at the $\mathrm{AD}$ facility in order to reach the requested amount of $\mathrm{H}_{2} \mathrm{~S}$ and to avoid malfunctioning in the micro-CHP units (Evangelisti et al., 2014). $\mathrm{CO}_{2}$ removal is achieved by Pressure Swing Adsorption (PSA) in which carbon dioxide is separated from the biogas by adsorption at elevated pressure. To reach the specification for grid injection, which differs for each country, further steps are required, including drying or adding other components such as Liquid Petroleum Gas (LPG) (Van Foreest, 2012). In this study, we consider the emissions associated with both upgrading the biogas to $97 \% \mathrm{v} / \mathrm{v}$ methane and increasing the calorific value to that of natural gas. Methane losses to the off-gas of 3\% are assumed for the upgrading process (Patterson et al., 2011). The calorific adjustment is achieved by adding $0.03705 \mathrm{~m}^{3}$ of liquid petroleum gas (LPG) per $\mathrm{m}^{3}$ of upgraded biomethane (Patterson et al., 2011). The associated electricity consumption is $1.1 \mathrm{MJ}$ per $\mathrm{m}^{3}$ of biogas, based on the study of Poschl et al., 2010 . 
The biomethane is assumed to be transported from the digester plant to individual dwellings. The average transport distance is taken as $8 \mathrm{~km}$ for each case study. The energy demand for compressing the gas for injection into the pipeline, from ambient pressure to 1.6 $\mathrm{MPa}$, is equivalent to $0.48 \mathrm{MJ} / \mathrm{m}^{3} \mathrm{~N}$ of biogas (Patterson et al., 2011; Poschl et al., 2010). Fugitive emissions of $0.7 \%$ are assumed for every $10 \mathrm{~km}$ of pipeline (Halliday et al., 2005).

\subsubsection{Micro-CHP systems}

The model considers the annual operation of the micro CHP system (time-step). The reference year chosen for the comparison is 2012. This is particularly important for technologies which are still being developed: in this context, the SOFC and Stirling engine.

Table 4 summarises the inventory data related to the micro-CHP units considered together with the assumptions used to estimate the direct emissions associated with the use of the micro-CHP systems.

A Stirling engine is an external combustion engine; this allows running with a variety of fuels, including biomass based fuels. An important characteristic of the Stirling engine is that the combustion process can occur in steady state and therefore it is easier to control compared with internal combustion engines. It also has the potential of achieving high global efficiencies because it closely approaches the Carnot cycle. However, its electrical efficiency is moderate, typically around 10 to $15 \%$ (Evangelisti, 2013a). An elementary Stirling engine consists of an engine piston, an exchanger piston and three heat exchangers: a cooler, a regenerator and a heater. The piston converts gas pressure into mechanical power, whereas the exchanger piston is used to move the working gas between the hot and cold sources. Several companies are developing Stirling units for CHP applications. The unit considered in this study is the Whispergen $1.2 \mathrm{kWe}$, developed by WhisperTech (New Zeland) and it is an alpha kinematic engine with 12 and $8 \%$ electrical and thermal efficiency, respectively (see Table 4).

Micro Gas Turbines are a specific type of gas turbines, with limited electrical power size compared with traditional gas turbine. They can offer several advantages compared with traditional technologies for small scale power generation, such as compact size and lowweight per unit power, multi-fuel capabilities as well as opportunities for lower emissions, and if compared with internal combustion engines, micro gas turbines show few balancing problems due to the absence of reciprocating and friction components (Pinelli, 2004). 
Capstone Turbine Corporation (US) is one of the leading companies in micro gas turbine market. They offer a marketable model for micro CHP application of $30 \mathrm{kWe}$ power run with biogas or natural gas. Example of installation is an array of 10 Capstone C65 micro turbines to supply heat and power to a 44,520 apartment complex in South Korea. Similar installations have been provided in Japan, while in Europe Capstone models are currently used in public space, such as hospitals or universities (Capstone Turbine, 2013).

The basic SOFC micro-CHP unit considered in this study is the ISM $1.7 \mathrm{~kW}$ Sunfire, currently installed in the Vaillant system in Germany for the Callux demonstration field program (Fuel Cell Today, 2012).The chosen fuel cell can run with both biomethane and biogas, given that it includes an internal steam reforming unit. The total (i.e. electrical and thermal) efficiency of the fuel cell is assumed to be $35 \%$ and $55 \%$ respectively for biogas and biomethane. A parasitic load equal to $2 \%$ of the total electricity produced is assumed for operation of the fuel cell system. Stack NOx emissions are taken as $0.003 \mathrm{~g} / \mathrm{m} 3 \mathrm{~N}$ of biogas/biomethane feed (Pehnt, 2008). A more comprehensive description of the solid oxide fuel cell system can be found in Evangelisti et al. (2014).

\subsubsection{Operating strategy}

A MS Excel model has been developed to predict the behaviour of each micro-CHP technology in the two geographical case studies (UK and Italy), considering different operating strategies (defined as external parameters in the model). As shown in Figure 2, the outputs of the model are: the amount of energy (both electricity and heat) produced by the micro-CHP system; the hours of operation of the energy unit in one year; the number of households that can be supplied to by the micro-CHP system fed with biomethane and the total environmental impact.

To represent all possible operating cases, the three following strategies are investigated:

1. Full Thermal demand $(F T)$ : the micro-CHP system is designed to fully satisfy the space heating demand of the dwelling over the year. Electricity is the by-product, and the amount produced depends on the Heat to Power ratio of the specific system. When the electricity produced is greater than the electricity demand of the house, the surplus electricity is sold back to the grid.

2. Half Thermal demand (HT): the micro-CHP system is designed to satisfy $50 \%$ of the space heating demand of the dwelling over the year with the remaining heat provided 
by the conventional technology, i.e. a natural gas condensing boiler. Also in this case, based on the $\mathrm{H}$ to $\mathrm{P}$ of each system, electricity is produced as by-product and it can be eventually sold to the grid.

3. Full Electricity demand (FE): the micro-CHP system is designed to fully satisfy the electricity demand of the dwellings. In this particular case, the thermal energy is the "by product", and it is supplied to the dwelling to provide part or all of the space heating demand. When surplus heat is produced, a district heating grid is assumed to receive the excess thermal energy.

Surplus electricity or thermal energy sold to the grid are considered as avoided burdens.

The three micro-CHP systems considered have different power outputs. In particular, the micro gas turbine has a power output of $30 \mathrm{kWe}$. Hence, the installation of a micro-grid is assumed to compare the three scenarios. Micro-grids are local distribution systems that contain generation plants and can run both in autonomous (stand-alone) and non-autonomous (grid-connected) mode. A micro-grid is usually operated by means of a control centre that monitors real-time energy demand and supply, optimizing the dispatch of dispersed generators, storage systems and acting on loads through demand response management. This concept is interesting in particular for integrated "smart" energy systems in district applications (Manfren et al., 2011).

Finally, $15 \%$ of thermal losses are assumed for the conversion of the waste heat produced in the micro-CHP unit into the space heating for the dwelling, due to the heat exchanger efficiency (Giannapoulis and Founti, 2011).

\section{RESULTS AND DISCUSSION}

In this section, the results of this study are presented. First, the different micro-CHP technologies are analysed, from an environmental impact point of view, through a hot spot analysis which identifies the most polluting processes in the foreground system. Then the outputs of the different micro-CHPs model technologies operated in the three operating strategies are compared in terms of energy produced, number of households served and hours of operation during the year. Finally, the relevance of the results on the geographic context is discussed, in particular in terms of marginal electricity production technologies.

\subsection{Comparison of alternative micro-CHP systems}


Figure 3 shows a hot spot analysis for the three micro-CHP technologies when operated to supply the full thermal demand of the households. The processes associated with the production of biomethane, including the collection of the OFMSW to the supply of the biofuel to the dwellings, are taken as the same for each technology analysed. As a consequence of this, the environmental impacts are constant for all of the technological scenarios. In Figure 1, the processes involved from the transport of the OFMSW up to the upgrading of the biogas to the biomethane are considered common to all the technology investigated. The life cycle impact assessment, in terms of GWP, AP and AD, is presented and discussed in this section. The trend of the results for the Photochemical Ozone Creation Potential and the Nutrient Enrichment categories are the same as for the GWP, AP and AD and only presented in Table 6. Only the most significant results are discussed in the following sections. Transport phase is not highlighted in the results, although included, because out of the scope of this LCA.

\subsubsection{Global warming}

The global warming potential is negative for all the micro-CHP technologies analysed. However, fuel cells are the most environmentally friendly solution compared with micro-GT and Stirling engine, with an overall saving of -32 kton of $\mathrm{CO}_{2}$ eq in the Italian area and -30 kton of $\mathrm{CO}_{2}$ eq in the $\mathrm{UK}$ area, per functional unit, compared with the reference scenario (see Figure 3-a and 3-d). The largest contribution to the saving (about $80 \%$ of the total) is given by the avoided emissions due to landfilling of the OFMSW, which is diverted to the biological treatment. The use of digestate on agricultural soil contributes to the saving by about $4 \%$. Amongst the processes that produce positive burdens, the largest contribution comes from the anaerobic digestion plant (between $45 \%$ and $65 \%$ depending on the micro-CHP scenario), while the upgrading of the biomethane contributes between $25 \%$ to $30 \%$. This is mainly due to direct fugitive emissions of methane during the upgrading process and to the indirect emissions associated with the electricity supplied to the PSA to achieve the required pressure.

The impact of using different technologies is noticeable in terms of avoided heat/electricity produced by the micro-CHP systems and supplied to the dwelling or sold back to the grid. The fuel cell supplies a larger amount of electricity to the grid in the Italian case compared with the other scenarios, and this is due to its higher electrical efficiency compared with the other micro-CHP technologies, and to the lower electricity demand per year of the average Italian household compared with the UK. 
Overall, the avoided emissions associated with the electricity production are higher than the avoided emissions associated with the heat production as shown in Figure 3. This is because of the larger footprint associated with the production of $1 \mathrm{kWh}$ of electricity from the grid compared with the burdens associated with the production of $1 \mathrm{kWh}$ of heat from a condensing boiler with natural gas.

\subsubsection{Acidification}

The Acidification Potential is shown in Figure 3-b and Figure 3-e. The total impact is negative for the fuel cell (both for the UK and Italian scenarios) and for the micro gas turbine in the Italian scenario. The total impact is positive for the Stirling engine scenario ( 8 ton of $\mathrm{SO}_{2}$ eq per functional unit) and for the micro gas turbine in the $\mathrm{UK}$ scenario (1 ton of $\mathrm{SO}_{2}$ eq per functional unit). The scenario with the Stirling engine is penalised by the missing credits for electricity sold to the grid which represent an avoided burdens for the other scenarios. On the other hand, the positive impact of the parasitic loads and micro - CHP use influence the results obtained for the micro-gas turbine scenario.

The avoided burdens allocated to landfill for the AP show proportionally less savings than those for the GWP(the avoided AP associated to landfill contributes to the total saving between $18 \%$ to $44 \%$ depending on the scenario considered). The biological treatment (considering both anaerobic digestion and digestate use) contributes $60 \%$ to $70 \%$ to the total positive burdens. This is mainly due to the electricity supplied to the anaerobic digestion plant and the emissions that occur during the spreading of digestate on the agricultural soil (Evangelisti et al., 2013b).

\subsubsection{Abiotic Depletion}

This category considers the depletion of non - living resources, i.e. fossil energy, and it can be used to estimate the primary non-renewable energy consumption in the system. The fuel cell and the micro gas turbine in the Italian scenario show a negative impact with the FC giving the highest savings. The Stirling engine, the fuel cell and the micro gas turbine scenarios in the UK context show instead a positive burden. This is primarily due to the higher parasitic load and hence higher consumption of fossil resources during the biological treatment due to the greater amount of OFMSW treated in the area of Greenwich compared with the area of Livorno in the Italian case study.

\subsection{Comparison of alternative operating strategies}


Table 5 shows the environmental impact assessment for the different micro-CHP technologies for the three operating strategies investigated (i.e. full thermal demand - FT; half thermal demand - HT: and full electricity demand - FE). The results reflect the amount of electricity and heat produced with the different micro - CHP systems, which is related to the specific $\mathrm{H}$ to $\mathrm{P}$ ratio of the micro-CHP technology and to the energy demand of the household.

The results showed in Table 5 are similar for the different impact categories within the three operating strategies investigated. This is because the environmental impact depends on the amount of biomethane available within the areas studied and which is assumed to be the same for the three operating strategies considered.

Figure 4 shows the amount of electricity and heat produced by each micro-CHP system, the operating hours and the number of households served, as a function of the operating strategy used and the technology installed. The results show that the scenario with the SE in the Italian context serves the highest number of household ( 6600) compared with the other technologies. However, this scenario is the least environmentally friendly of the micro-CHP systems considered in the Italian context (see Table 5). This is because it is characterized by the highest $\mathrm{H}$ to $\mathrm{P}$ ratio, hence giving the lowest amount of electricity produced - then requiring the highest amount of electricity from the grid.

Nevertheless, four scenarios, namely FC-UK-FT; FC-UK-HT; FC-IT- FT; and SE - UK - FE, exceed the maximum number of hours per year (see Table 4) allowed for the specific technology, as shown in Figure 4-b and d. This is a consequence of initially not constraining the number of hours of operation within the model. Further analysis has subsequently been done to assess the performance of these scenarios within the limit of the real lifetime of each technology considered against the unconstrained lifetime scenarios, hereinafter referred as baseline scenario. Results are presented in Table 6. The GWP shows a significant variation in the FC-UK-FT scenario and in the SE-UK-FE scenarios, although the discrepancy is less than $10 \%$ compared with the baseline scenario. The most noticeable results are for the FC-UK-FT scenario where, imposing a limited lifetime of the fuel cell causes the fossil fuel resources consumption to increase 4 times compared with the baseline scenario. By limiting the number of hours of operation of the fuel cell to 2700 hours per year, the single micro-CHP system cannot supply the requested thermal energy to the dwelling and therefore an additional boiler fed with natural gas (from fossil sources) has to be installed to fulfil the thermal demand. 


\subsection{Relevance of the geographic context}

The environmental impacts associated with the distributed generation scenarios are different in the two geographic areas analysed. It is possible to identify three key parameters related with the geographic context which can affect the environmental impact of a micro CHP system fed by OFMSW in the distributed generation paradigm. These are:

- The $\mathrm{H}$ to $\mathrm{P}$ ratio of the demand side (influenced by geographic and climate conditions): this study shows how the same technology applied in two different geographic contexts can lead to either environmental savings or to environmental burdens. This can be related to the assumptions made on the heating demand of the house in the two contexts, which is the conventional parameter used to identify the climate conditions of the area considered

- The quantity of OFMSW locally available as feedstock: this determines the amount of biomethane produced and supplied to the micro-CHP system (the input of the model in Figure 2), affecting the number of installation and consequently the total environmental impact of the system;

- The country-specific average mix of technologies and resources used to produce heat and electricity to the dwelling, as assumed in the definition of the reference scenario.

In particular, the electricity sold to the grid and supplied to the dwelling is assumed to substitute by $100 \%$ the mix of technologies used in the UK and the Italian grid. Previous studies point out the importance of choosing the right technology to replace the micro CHP installation. In a dynamic system, such as energy systems, an increase in energy demand will likely affect both the base-load and the peak-load production technologies (Pehnt, 2008). A further analysis is then presented in Figure 5 to highlight the changes in the results when a marginal electricity production technology is assumed in the reference scenario for both the UK and Italy. A comparison between natural gas and coal for the marginal electricity production technologies shows no change for the GWP impact trend; however, as expected, the savings are higher for the coal plant scenario because of the higher avoided emissions coming from the electricity produced with the micro-CHP systems. The trend for the AP impact is instead different as shown in Figure 5-b. All the micro-CHP scenarios provide a saving when compared to the reference scenario with a coal power plant; the environmental 
impact becomes instead positive when the natural gas is assumed as the main resource for electricity production. As expected, the average electricity mix assumed at the beginning of the study show an average between the two marginal technologies. Finally, the trend for the abiotic depletion impact category decreases in all scenarios when a marginal technology (either coal or natural gas power plant) is assumed in the reference scenario.

The results of this study confirmed what reported by by Penht (2008) specifically for micro CHP system and Halliday et al (2005). Additionally, Pehnt analysed a large scale Stirling engine, concluding that this is the most environmentally friendly solution, considering its higher total efficiency.

\section{DISCUSSION AND CONCLUSIONS}

In this section a summary of the main findings of the study is presented, based on the driving questions presented in Section 1.2.

This study has demonstrated that the type of bio-methane fed micro-CHP technology employed (i.e. fuel cells, sterling engine, micro-gas turbine) has a significantly different environmental impact: fuel cells are the most environmentally friendly solution in every impact category analysed; stirling engines although can supply heat to the largest number of dwellings are the least environmentally friendly technology. The operating strategy adopted for a chosen technology and the geographic context considered influence the performance and output of the different micro-CHP systems investigated in this paper. The results show that whilst the operating strategy (full thermal demand, half thermal demand and full electricity demand) of the micro-CHP systems studies, does not influence the environmental impact of the specific micro-CHP technology, it determines instead the amount of energy (electricity and heat) supplied to the dwellings and exported to the grid. For example, for all three technologies investigated, the amount of electricity generated by the micro-CHP systems and supplied to the dwellings is higher when the full electricity (FE) operating strategy is adopted; in this case, the amount of electricity exported to the grid is in turn lower than with the other operating strategies studied.

In order to compare the FC with a traditional technology, a further analysis has been presented for the UK. Figure 6 shows the system boundary for the comparison between a traditional energy production system-constituted by an internal combustion engine for macro generation which is directly fueled by biogas and the abovementioned micro-CHP FC system 
(FE operating strategy for the UK). The ICE unit was the same investigated in Evangelisti et al. 2014 (for further details about system characteristic refer to the previous publication by the same author). The results for the GWP are presented in Table 7. The biogas + ICE system shows a slightly higher impact compared with the FC system, which represents again the most environmentally friendly solution. It is worth noticing that in this further analysis only avoided burdens due to electricity produced by the energy production systems were considered as the systems were assumed to be operating in the FE strategy.

The effect of the geographic context on the environmental impact of the micro-CHP technologies is instead more pronounced than the operating strategy. As shown in Section 3.1, the results obtained for the specific technology can lead decision makers to conflicting decisions depending on the environmental category considered. For example, a micro gas turbine can lead to environmental savings in terms of acidification potential - compared with the reference scenario - when installed in the Livorno area (Italy) while it would represent an environmental burden when placed in Greenwich (UK). The geographical context influences also the choice for the marginal electricity production technology assumed in the reference scenario. Although the results do not show a significant variation in terms of GWP when the UK or Italian scenarios are compared (Figure 5.a), the supply chains of fossil resources (i.e. coal and natural gas) specific to the geographical context impact differently on the final abiotic depletion obtained for the technologies investigated (see Figure 5.c).

All technologies investigated are in their early stage of being marketable products, such as micro GT, or still in development (fuel cells and Stirling engine). Especially for the fuel cell, the main operating conditions might change rapidly in the next few years and the efficiency may thus become higher than the value considered in this study. Furthermore a quantification of the emissions from the micro-CHP systems are still under evaluation, given that only few field trials have been carried out to determine the environmental impact of a micro cogeneration system when installed in a real dwelling.

Nevertheless, the thermal efficiency of a micro-CHP system depends strongly on its operating temperatures and its thermal cycle's limitation. The recovering of the heat is, theoretically, possible in every cogeneration system. Practically, it is more an economic evaluation than an environmental consideration (Pehnt, 2008). 
In this paper, the results show that the environmental impact of supplying energy to households in Europe can be reduced when micro-CHP systems fed with biomethane produced by OFMSW are installed. However, depending on the factors investigated in the model presented here (energy produced, hours of operation, number of households served and the environmental impact), the type of technology adopted and the operating strategy implemented will influence the decision making process.

\section{REFERENCE}

Berglund, M., Börjesson, P., 2006. Assessment of energy performance in the life-cycle of biogas production. Biomass and Bioenergy 30 (3), 254-266. http://dx.doi.org/10.1016/j.biombioe.2005.11.011.

Boldrin A, Neidel TL, Damgaard A, et al. 2011. Modelling of environmental impacts from biological treatment of organic municipal waste in EASEWASTE. Waste management (New York, N.Y.); 31(4): 619-30.

Borello D, Evangelisti S, Tortora E. 2013. Modelling of a CHP SOFC System Fed with Biogas from Anaerobic Digestion of Municipal Waste Integrated with Solar Collectors and Storage Unit. International Journal of Thermodynamics; 16: 28-35.

Capstone Turbine Corporation. [Online]. 2013. Available from: http://www.capstoneturbine.com/prodsol/products/ [Accessed: 24 March 2013].

CCC (Committee on Climate Change), 2008. Building a Low-Carbon Economy - The UK's Contribution to Tackling Climate Change. TSO. <http://archive.theccc.org.uk/aws3/TSOClimateChange.pdf $>$ (accessed 19.03.13).

Clift R, Doig A, Finnveden G. 2000. The Application Of Life Cycle Assessment To Integrated Solid Waste Management Part 1-Methodology. Institution of Chemical Engineers Trans IchemE; 78.

Clift R. 2013. System Approaches: Life Cycle Assessment and Industrial Ecology. Chapter 17 in: R.M. Harrison Royal Society of Chemistry Pollution (eds): Causes, Effects and Control; 5th Ed; London.

Dalemo M, Sonesson U, Bjorklund A et al. 1997. ORWARE a simulation model for organic waste handling systems - Part 1 model description. Resources, Conservation and Recycling; 21:17-37. 
DECC, 2011. Microgeneration strategy, DECC (Department of Energy and Climate Change), UK Government.

https://www.gov.uk/government/uploads/system/uploads/attachment_data/file/48114/2015microgeneration-strategy.pdf [March 2013].

DECC, 2013. The future of heating: Meeting the challenge, DECC (Department of Energy and Climate Change), UK Government. https://www.gov.uk/government/uploads/system/uploads/attachment_data/file/190149/16_04DECC-The_Future_of_Heating_Accessible-10.pdf [June, 2016]

EPA, 2011. ccounting Framework for Biogenic CO2 Emissions from Stationary Sources. US Environmental Potection Agency (EPA), Office of Atmospheric Programs, Climate Change Division; Washington,

DC. <http://www.epa.gov/climatechange/Downloads/ghgemissions/Biogenic-CO2-AccountingFramework-Report-Sept-2011.pdf> [March 2013].

Eriksson O, Finnveden G, Ekvall T, Borkjolund A. 2007. Life cycle assessment of fuels for district heating: A comparison of waste incineration, biomass- and natural gas combustion. Energy Policy; 35(2): 1346-62.

European Union, 2009. Directive 2009/28/EC of 23 April 2009 on the promotion of the use of energy from renewable sources and amending and subsequently repealing Directives 2001/77/EC and 2003/30/EC. European Parliament and the Council, Official Journal of the European Union.

<http://eurlex.europa.eu/LexUriServ/LexUriServ.do?uri=Oj:L:2009:140:0016:0062:en:PDF> [March 2013].

European Union, 2010. COM 235: Communication from the Commission to the Council and the European Parliament on Future steps in bio-waste management in the Euroepan Union. European Commission. 〈http://ec.europa.eu/environment/waste/compost/pdf/com biowaste.pdf> [March 2013].

EUROSTAT, 2011. Waste Management in Europe. [Online]. 2011. Available from: <http://epp.eurostat.ec.europa.eu/statistics_explained/index.php/Municipal_waste_statistics> [Accessed: 1 December 2012]. 
Evangelisti, S. 2013a. Life Cycle Assessment of distributed energy production using biofuel from waste. $\mathrm{PhD}$ dissertation, Sapienza University of Rome, Italy. [Online]. Available at: http://hdl.handle.net/10805/2107 [last access: 22 August, 2013].

Evangelisti S, Lettieri P, Borello D, Clift R. 2013b. Life Cycle assessment of energy from waste via anaerobic digestion: a UK case study. Waste Management; 34 (1): 226-37.

Evangelisti S, Lettieri P, Borello D, Clift R. 2014. Distributed generation by energy from waste technologies: a life cycle perspective. Process, Safety and Environmental Protection; http://dx.doi.org/10.1016/j.psep.2014.03.008

Fisher, K., Collins, M., Aumonier, S., Gregory, B., 2006. Carbon Balances and Energy Impacts of the Management of UK Wastes. Final Report, Prepared by DEFRA, R\&D Project WRT 237.

Fruergaard, T., Astrup, T., Ekvall, T., 2009. Energy use and recovery in waste management and implications for accounting of greenhouse gases and global warming contributions. Waste Management and Research 27 (8), 724-737.

Giannopoulos D, Founti M. 2011. Parametric comparative analysis of lifetime energy demand and CO2 -eq savings of a SOFC m-CHP unit. Proceedings of the European Fuel Cell Forum; 28 June - 1 July; Lucerne, Switzerland.

Guineè J B (Ed.). 2002. Handbook on Life Cycle Assessment, Operational Guide to the ISO Standards. Kluwer Academic Publishers; Dordrecht.

Halliday J, Ruddell A, Powell J, Peters M. (Tyndall Centre). 2005. Fuel Cell Fuel cells: providing heat and power in the urban environment. Final Report. Technical Report No. 32; Tyndall Research Project N. IT1.36.

Hawkes A D, Aguiar P, Croxford B, Leach M A, Adjiman C S, Brandon N P. 2007. Solid oxide fuel cell micro combined heat and power system operating strategy: Options for provision of residential space and water heating. Journal of Power Sources; 164(1): 260-71 ISO, 2006. Environmental management - life cycle assessment - principles and framework. International Standards Organization (ISO); N. ISO 14040; Geneva.

ISPRA, 2012. Municipal solid waste report 2012 (italian), ISPRA (Istituto Superiore per la Protezione e la Ricerca Ambientale); 2012; Italy. Available at: <http://www.isprambiente.gov.it/files/pubblicazioni/rapporti/rifiuti2012/rapporto-rifiuti-2012estratto.pdf>. 
ISTAT, 2012. Resident population in Livorno in 2012 (online) (italian), ISTAT (Istituto di Statistica nazionale) [updated 2013; accessed 1 march 2013]. Available at: http://demo.istat.it/pop2012/index.html

Italian Parliement, 2012. Law n. 134/2012 - Conversione in legge, con modificazioni, del decreto-legge 22 giugno 2012, n. 83, recante misure urgenti per la crescita del Paese; Italian Parliament; Published on the Gazzetta Ufficiale (GU) n. 187 of 11/08/2012 - supplement n. 171.

Liso V, Zhao Y, Brandon N, Nielsen MP, et al. 2011. Analysis of the impact of heat-to-power ratio for a SOFC-based $\mathrm{mCHP}$ system for residential application under different climate regions in Europe. International Journal of Hydrogen Energy; 36 (21): 13715-26.

Lunghi P, Bove R, Desideri U. 2004. LCA of a molten carbonate fuel cell system. Journal of Power Sources; 137(2): 239-47.

Manfren, M., Caputo, P., Costa, G. 2011. Paradigm shift in urban energy systems through distributed generation: methods and models. Applied Energy. 88 (4), 1032 - 1048.

Manfredi S, Pant R. 2011 (European Commission - Joint Research Centre and Institute of Environmental Sustainability). Supporting Environmentally Sound Decisions for Bio-Waste Management: A practical guide to Life Cycle Thinking (LCT) and Life Cycle Assessment (LCA). European Commission. Report N. EUR 24917 EN - 2011. <doi:10.2788/53942> [March 2013].

Fuel Cell Today The Fuel Cell Industry Review 2012. Royston, UK (2012) Mezzullo WG, McManus MM, Hammond GP. 2013. Life cycle assessment of a small-scale anaerobic digestion plant from cattle waste. Applied Energy; 102: 657-64.

Møller J, Boldrin A, Christensen T H. 2009. Anaerobic digestion and digestate use: accounting of greenhouse gases and global warming contribution. Waste Management \& Research; 27: 813-24.

MTT Agrifood research Finland and Maa Ja Elintarviketalouden Tutkimuskeskus. 2010. 1-54 Valorisation of food waste to biogas project - Compositional analysis of food waste from study sites in geographically distinct regions of Europe. Deliverable report for the European Project "Valorisation of food waste to biogas", Grant agreement n. 241334.

PAS 110, 2010. Specification for whole digestate, separated liquor and separated fibre derived from the anaerobic digestion of source-segregated biodegradable materials. British Standards Institution (BSI); Standart n. PAS 110; London (UK). 
PAS 2050, 2011. or the Assessment of the Life Cycle Greenhouse GasEmissions of Goods and Services. British Standards Institution (BSI); Standard n. PAS 2050; London.

Patterson T, Esteves S, Dinsdale R, Guwy A. 2011. Life cycle assessment of biogas infrastructure options on a regional scale. Bioresource technology; 102: 7313-23.

PE International, 2014. GaBi stustainability software, database version 6.610. Available at: http://www.gabi-software.com/uk-ireland/software/gabi-software/

Pehnt M. 2008. Environmental impacts of distributed energy systems - The case of micro cogeneration. Environmental Science \& Policy; 11: 25-37.

Pinelli, M. 2004. Problematiche ed esperienze nell'utilizzo di turbogas alimentati a biogas. In Biomasse a fini energetici, Enea.

Pöschl M, Ward S, Owende P. 2010. Evaluation of energy efficiency of various biogas production and utilization pathways. Applied Energy; 87(11): 3305-21.

Royal Borough of Greenwich, 2011. Available from: < http://www.royalgreenwich.gov.uk/info/200088/statistics_and_census_information/106/censu s_2011>.

Staffell I, Ingram A, Kendall K. 2011. Energy and carbon payback times for solid oxide fuel Turconi, R., Butera, S., Boldrin, A., Grosso, M., Rigamonti, L., Astrup, T., 2011. Life cycle assessment of waste incineration in Denmark and Italy using two LCA models. Waste Management and Research 29 (10), 78-90. http://dx.doi.org/10.1177/0734242X11417489

.cell based domestic CHP. International Journal of Hydrogen Energy; 37(3): 2509-23.

Van Foreest, 2012. Perspectives for Biogas in Europe. Oxford Institute for Energy Studies. Available from: http://www.oxfordenergy.org/wpcms/wp-content/uploads/2012/12/NG70.pdf.

Weidema, B.P., Frees, N., Nielsen, A., 1999. Marginal production technologies for life cycle inventories. Energy 4 (1), 48-56.

Wenzel H, Hauschild M, Alting L (eds). 1997. Environmental assessment of products. Vol.1: Methodology, tools and case studies. Kluwer Aca.

WRAP, 2011. Digestate \& compost in agricultural project - Bulletin n. 1 and 2, Waste and Recycling Action Programme (WRAP) - UK; March and November 2011.

Zhang, S., Bi, T., Clift, R. 2013. A Life Cycle Assessment of integrated dairy farmgreenhouse systems in British Columbia, Bioresource Technology, 150: 496-505. 